\title{
Population Dynamics, Fecundity and Fatty Acid Composition of Oithona nana (Cyclopoida, Copepoda), Fed on Different Diets
}

\author{
Fawzy I. Magouz ${ }^{1}$, Mohamed A. Essa ${ }^{2}$, Mustafa Matter ${ }^{2}$, Abdallah Tageldein Mansour ${ }^{3,4, * \mathbb{D} \text {, }}$ \\ Mohamed Alkafafy ${ }^{5}$ (D) and Mohamed Ashour ${ }^{2, *(D)}$ \\ 1 Department of Animal Production, Faculty of Agriculture, Kafrelsheikh University, \\ Kafrelsheikh 33516, Egypt; fawzymagouz@yahoo.com \\ 2 National Institute of Oceanography and Fisheries (NIOF), Cairo 11516, Egypt; messa51@yahoo.com (M.A.E.); \\ mhsy4@yahoo.com (M.M.) \\ 3 Animal and Fish Production Department, College of Agricultural and Food Sciences, King Faisal University, \\ P.O. Box 420, Al-Ahsa 31982, Saudi Arabia \\ 4 Fish and Animal Production Department, Faculty of Agriculture (Saba Basha), Alexandria University, \\ Alexandria 21531, Egypt \\ 5 Department of Biotechnology, College of Science, Taif University, P.O. Box 11099, Taif 21944, Saudi Arabia; \\ m.kafafy@tu.edu.sa \\ * Correspondence: amansour@kfu.edu.sa (A.T.M.); microalgae_egypt@yahoo.com (M.A.)
}

check for

updates

Citation: Magouz, F.I.; Essa, M.A.; Matter, M.; Tageldein Mansour, A.; Alkafafy, M.; Ashour, M. Population Dynamics, Fecundity and Fatty Acid Composition of Oithona nana (Cyclopoida, Copepoda), Fed on Different Diets. Animals 2021, 11, 1188. https://doi.org/10.3390/ani11051188

Academic Editor: Benedetto Sicuro

Received: 4 March 2021

Accepted: 19 April 2021

Published: 21 April 2021

Publisher's Note: MDPI stays neutral with regard to jurisdictional claims in published maps and institutional affiliations.

Copyright: (c) 2021 by the authors. Licensee MDPI, Basel, Switzerland. This article is an open access article distributed under the terms and conditions of the Creative Commons Attribution (CC BY) license (https:// creativecommons.org/licenses/by/ $4.0 /)$.
Simple Summary: Marine larval production is the most critical stage in the life of the marine aquacultured species, which depends on the use of different zooplanktonic organisms as live feed. Copepods are high-quality live prey that could be efficiently used to overcome the transition period from live food to weaning with an artificial diet in the post-larval stages. The main culture systems of copepods use microalgae as uni-food, nevertheless for the more sustainable and cost-efficient production of copepods, the development of artificial diets is the core of its production techniques. The present study was conducted to improve the production and nutritional quality of copepod, Oithona nana, using different diets (soybean, yeast, rice bran, and corn starch). Among all diets, corn starch revealed the highest population growth. Meanwhile, animals nourished by rice bran showed the highest percent of copepodite, nauplii, and fecundity. The nutritional quality of copepods referred to fatty acids profile showed a high percentage of unsaturated fatty acids in copepods fed on rice bran. In conclusion, the dry feeds are very applicable, more economic, and simply alternative diets to substitute microalgae and maximize the fecundity and population of $O$. nana in fish hatcheries.

Abstract: The marine copepod species Oithona nana is considered as one of the most successfully mass cultured Cyclopoida species in marine hatcheries. This study investigated the effects of four feed diets (soybean, yeast, rice bran, and corn starch) on the population growth, growth rate, population composition, fecundity, and fatty acid composition of native isolated Cyclopoida copepod species $O$. nana. The experiment was continued for 15 days and the copepods were fed on one of the four diets with a concentration of $1{\mathrm{~g} 10^{-6} \text { individual day }}^{-1}$. The results revealed that corn starch was found to be the most supportive diet for population growth and population growth rate. For nutritional value, copepods fed on rice bran were detected to have the highest content of MUFA, PUFA, and the lowest SFA and SFA/UFA ratio; more importantly, the rice bran diet was the only treatment that showed C20:5w3. Moreover, copepods fed on rice bran showed the highest significant female fecundity, copepodite, and nauplii percent. Finally, the protocols described in the current study concluded that the dry feeds, especially corn starch, are very useful and applicable in hatcheries for maximizing the fecundity and density of Cyclopoida copepod species, O. nana.

Keywords: live feeds; artificial diets; fatty acid profile; Oithona nana; larvae rearing 


\section{Introduction}

Live feeds are the most important basic diet in marine hatcheries [1-3]. Many live feed species meet the nutritional requirements of marine larvae, therefore, live feeds are considered a mobile carrier of nutritive substances for marine larvae and postlarvae [4-7].

Copepods are one of the most nutritious live feeds used in marine hatcheries. Despite rotifer and artemia which were extensively used as preys in marine hatcheries $[8,9]$, copepods species are considered the best live prey, due to their higher nutritional value [4,10-14]. The ocean is the major source of cultured copepods and different culture methods of copepods have been referenced in recent years from the World Copepod Culture Database [4]. In truth, there are more than 60 copepod species that have been successfully cultured under laboratory conditions [15], while almost 30 culture methods have been reported [16,17].

In the aquatic environment, copepods serve as trophic linkages in marine ecosystems, connecting primary producers and secondary consumers $[10,18,19]$. Copepods play important roles in pelagic marine food webs [20], especially gelatinous zooplankton "jellyfish" that usually fed on copepods, which nowadays increase global concern for other important environmental topics, such as plastic pollution, which affect all zooplanktonic organisms [21]. Among copepods, the order Cyclopoida is considered the main organic matter consumer and energy transporter to higher trophic levels, including small fish, larvae, and juveniles of aquatic species in the marine ecosystem. Thus, Cyclopoida represents a major prey source for mesopelagic and bathypelagic fish $[19,22]$. Cyclopoida copepods, especially species Oithona nana, is an excellent source of highly polyunsaturated fatty acids, which make copepods more nutritious and attractive food for larval and small fish [4].

Selecting a suitable diet for copepods is a crucial factor that extensively influences the quantity and quality of cultured copepods [23-25]. Microalgae are the basic live diet utilized in marine hatcheries for copepod cultures due to many factors, such as nutritional value, size, shape suitability, and digestibility [25-27]. In addition, macro and/or microalgal cells are an attractive natural source of bioactive molecules, strongly recommended and needed for the growth and development of copepods and other marine aquatic organisms, including polyunsaturated fatty acid (PUFA), monounsaturated fatty acid (MUFA), saturated fatty acid (SFA), phenols, flavonoids, hydrocarbons, antimicrobial substances [28-30]. Lee et al. [31] evaluated the use of different microalgal diets reproductive and productive performance of a Cyclopoida copepod, Paracyclopina nana. Five single diets were used including Phaeodactylum tricornutum (PHA), Isochrysis galbana (ISO), Tetraselmis suecica (TET), marine Chlorella $(\mathrm{MCH})$, condensed freshwater Chlorella $(\mathrm{FCH})$, and the two mixed diets of TET + ISO and TET + PHA, which concluded that females fed TET + PHA and TET + ISO had a higher fecundity than female fed the five single diets. The nauplii fed ISO, TET, TET + PHA, and TET + ISO diets developed into adults, while no nauplii developed into adult when fed $\mathrm{MCH}, \mathrm{FCH}$, or PHA. The community of P. nana fed PHA was significantly lower than those fed TET, ISO, TET + PHA, and TET + ISO diets. While the community of $P$. nana fed FCH and $\mathrm{MCH}$ showed negative growth, however, the high labor and high production cost of microalgae increase the copepods' price of production. Subsequently, seeking an optimal diet as an alternative to the microalgal diet for copepods species is critical for sustainable fresh and marine aquaculture, in particular for cultured species that have commercial prospects.

Many feeding regimes were referenced as alternatives to the microalgal diet for different cultured copepods and zooplankton species, in general, such as baker's yeast Saccharomyces cerevisiae [32,33], fish diet [34], soybean [27], rice bran [35,36], starch and albumen [37], and glucose [38]. According to the previous references, the alternative feeding regimes for culturing either copepods or zooplankton species resulted in adequate population growth and productivity, depending on the cultured species, culture methods, and experimental conditions. However, studying the effects of feed types on copepod quality and quantity is remains necessary to determine their ideal prospect in marine aquaculture.

Cyclopoida copepods, O. nana, cultured under controlled laboratory conditions, were enriched with mixed diets of soybean $\left(1 \mathrm{~g} 10^{-6}\right.$ ind. $\left.24 \mathrm{~h}^{-1}\right)$ and Nannochloropsis oceanica 
$\left(5 \times 10^{6}\right.$ cells $\left.\mathrm{mL}^{-1}\right)$ and were utilized as live feed, resulting in improved growth performance, intestine histology, and the economic viability of European seabass (Dicentrarchus labrax) postlarvae [39]. Baker's yeast, Saccharomyces cerevisiae, could be successively used as an algal substitute for rotifer in marine hatcheries [40]. In addition, rice bran starch was successfully used as feed for copepods, daphnia artemia, and moina cultures [35,41,42].

To select the optimal feed for the Cyclopoida copepod, O. nana, the current study was conducted to evaluate the population growth, population growth rates, population compositions, fecundity, and fatty acid compositions of $O$. nana fed on commercial-grade soybean, yeast, rice bran, and corn starch diets.

\section{Materials and Methods}

\subsection{Copepods Stock Culture}

The marine copepods were isolated from an earthen pond at El-Max Research Station, Alexandria Branch of National Institute of Oceanography \& Fisheries, (NIOF), Egypt. During the copepod collections period in spring 2017, the earthen pond temperature $\left(23 \pm 2{ }^{\circ} \mathrm{C}\right)$, salinity $(31 \pm 1 \mathrm{ppt})$, and $\mathrm{pH}(7.37 \pm 0.10)$ were recorded at noon. Copepod samples were collected following the protocol described by Abo-Taleb et al. [6]. Isolated individuals were initially examined using a binocular stereomicroscope (Optika Microscopes, B190/B-290, Ponteranica, Italy). Morphological identification and taxonomic characterization were conducted by the Hydrobiology Lab., Marine Environment Division, NIOF. After morphological classification, the isolated adult copepods were identified as $\mathrm{Cy}$ clopoida: Oithona nana (Figure 1). Adult individuals of $O$. nana were maintained under controlled laboratory conditions $\left(27 \pm 1{ }^{\circ} \mathrm{C}, 20 \mathrm{ppt}, \mathrm{pH} 7.7 \pm 0.15\right.$, and continuous gentle aeration) and enriched with soybean and microalga Nannochloropsis oceanica NIOF15/001 $\left(5 \times 10^{6}\right.$ cells $\left.\mathrm{mL}^{-1}\right)$.

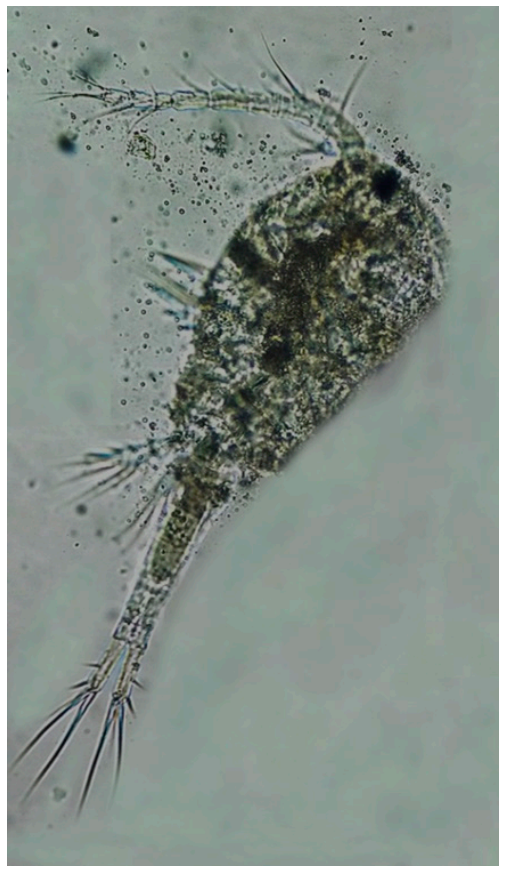

(A)

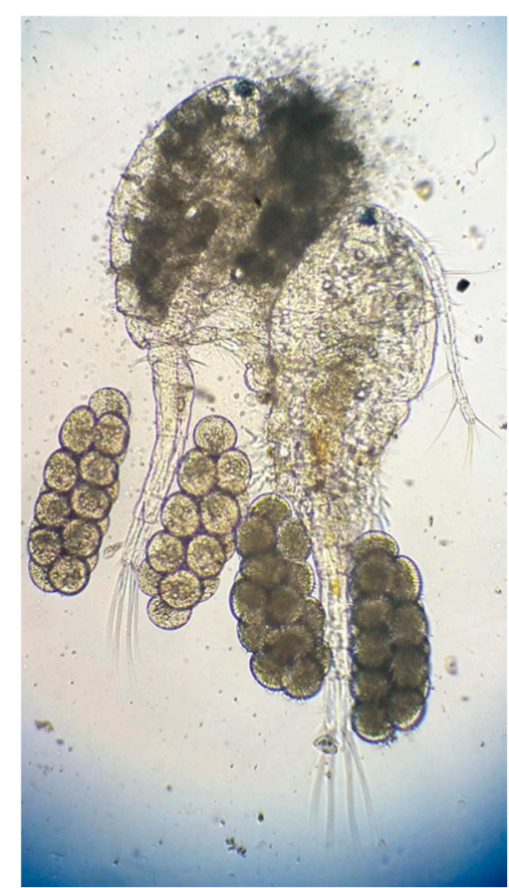

(B)

Figure 1. Isolated adult Copepoda, Cyclopoida: Oithona nana: (A) male; and (B) female.

\subsection{Regime and Experimental Design}

Commercial grade soybean, yeast (Saccharomyces cervicates), rice bran, and corn starch were used as feed for the copepods. Yeast (S. cervicates) and corn starch were supplied by the Starch and Yeast Company, Egypt, while soybean and rice bran were supplied by the Fish Feed Factory located in Alexandria, Egypt. The copepod individuals were 
divided into 4 groups with 4 various diets: soybean, yeast, rice bran, and corn starch, with concentration of $1 \mathrm{~g}$ for $10^{6}$ individual for $24 \mathrm{~h}$ of each. To prepare the concentration of soybean, yeast, rice bran, and corn starch (three replicates for each treatment), $1 \mathrm{~g}$ of a commercial S. cervicates, corn starch, a very finely grounded commercial soybean, and rice bran were dissolved separately in $100 \mathrm{~mL}$ of warm water $\left(35-45^{\circ} \mathrm{C}\right)$, shaken vigorously, and then blended using a kitchen mixer until fresh instant emulsion was formulated to be used for the enrichment of the different treatments in the feeding regimes [27]. The experiment was continued for 15 days.

The density of copepods in each group was estimated as individual $\mathrm{mL}^{-1}$ and the needed concentration for each group was estimated depending on the previously accounted copepods every three days (day-0, day-3, day-6, day-9, day-12, and day-15). Before the start of the experiment, the copepods were harvested from the stock culture tank and transferred to the new culture water for a $24 \mathrm{~h}$ gut evacuation to prevent the effects of resident soybean and algal diet $[25,43]$. At the beginning of the experiment, the individuals of adult copepods $O$. nana (average size: $625 \mu \mathrm{m}$ ) were cultured in glass tanks field with $30 \mathrm{~L}$ of $1 \mu \mathrm{m}$ bag-filtered, chlorine-disinfected of diluted seawater $(20 \mathrm{ppt})$ with initial stock density of approximately 1 individual $/ \mathrm{mL}$ (about 1000 ind. $\mathrm{L}^{-1}$ ). The culture conditions during the experiment were kept under controlled conditions of salinity $20 \mathrm{ppt}$, temperature $27 \pm 1{ }^{\circ} \mathrm{C}$ (using a digital thermometer), and $\mathrm{pH} 7.7 \pm 0.15$. The tanks were conducted without water replacement and were supplied with gentile aeration to keep dissolved oxygen (DO) over $4 \mathrm{mg} \mathrm{L}^{-1}$ (measured using Oxymeter, China). Ammonia $\left(\mathrm{NH}_{3}\right)$ concentration (measured using digital multi-meter, Italy) was $<0.45 \pm 0.05 \mathrm{mg} \mathrm{L}^{-1}$ in all treatments, and showed no negative effects of food regimes additions.

\subsection{Tested Parameters}

\subsubsection{Population Growth, Growth Rate, Composition, and Fecundity}

Every three days, $25 \mathrm{~mL}$ of culture water from every replicate of each diet was taken to estimate the population growth of copepods, which estimated the increase in the number of animals (ind. $\mathrm{mL}^{-1}$ ). Every 3 days, about one hundred individuals from each replicate were harvested, using a $38 \mu \mathrm{m}$ mesh, and fixed with a $4 \%$ formalin solution to estimate the percentage of population composition and different developmental stages (nauplii, copepodite, male, and female) under a microscope (Optika Microscopes, B190/B-290, Ponteranica, Italy). Twenty to thirty vigorous carrying-females from every replicate were sorted and placed on a Petri dish to examine the fecundity. The population growth rate $(r)$ was calculated according to Yin et al. [44], using the following equation:

$$
\mathrm{R}=\left(\ln \mathrm{N}_{\mathrm{t}}-\ln \mathrm{N}_{0}\right) / \mathrm{t}
$$

where $\mathrm{N}_{0}$ and $\mathrm{N}_{\mathrm{t}}$ are the initial and final population densities, and $\mathrm{t}$ is the incubation time in days.

\subsubsection{Fatty acid Analysis}

At the end of the experiment (after day-15), all copepods of each replicate were harvested and preserved at $-80^{\circ} \mathrm{C}$ for fatty acid analysis. The fatty acid of $O$. nana fed different diets were extracted and fatty acids profiles were estimated as described by El-Shenody et al. [45].

\subsubsection{Data Analysis}

Statistical analyses were analyzed using SPSS Version 16 . The results are presented as the mean \pm standard error $(n=3)$. All variables were evaluated in three replicates using one-way analysis of variance (ANOVA) followed by Duncan's multiple range tests to compare the differences among individual means at a significance level of $p \leq 0.05$. 


\section{Results}

\subsection{Population Growth, Growth Rate, Composition and Fecundity}

The population growth (ind. $\mathrm{L}^{-1}$ ), growth rate $(r)$, population composition, and fecundity of $O$. nana were significantly affected by different diets (Figures 2-5).

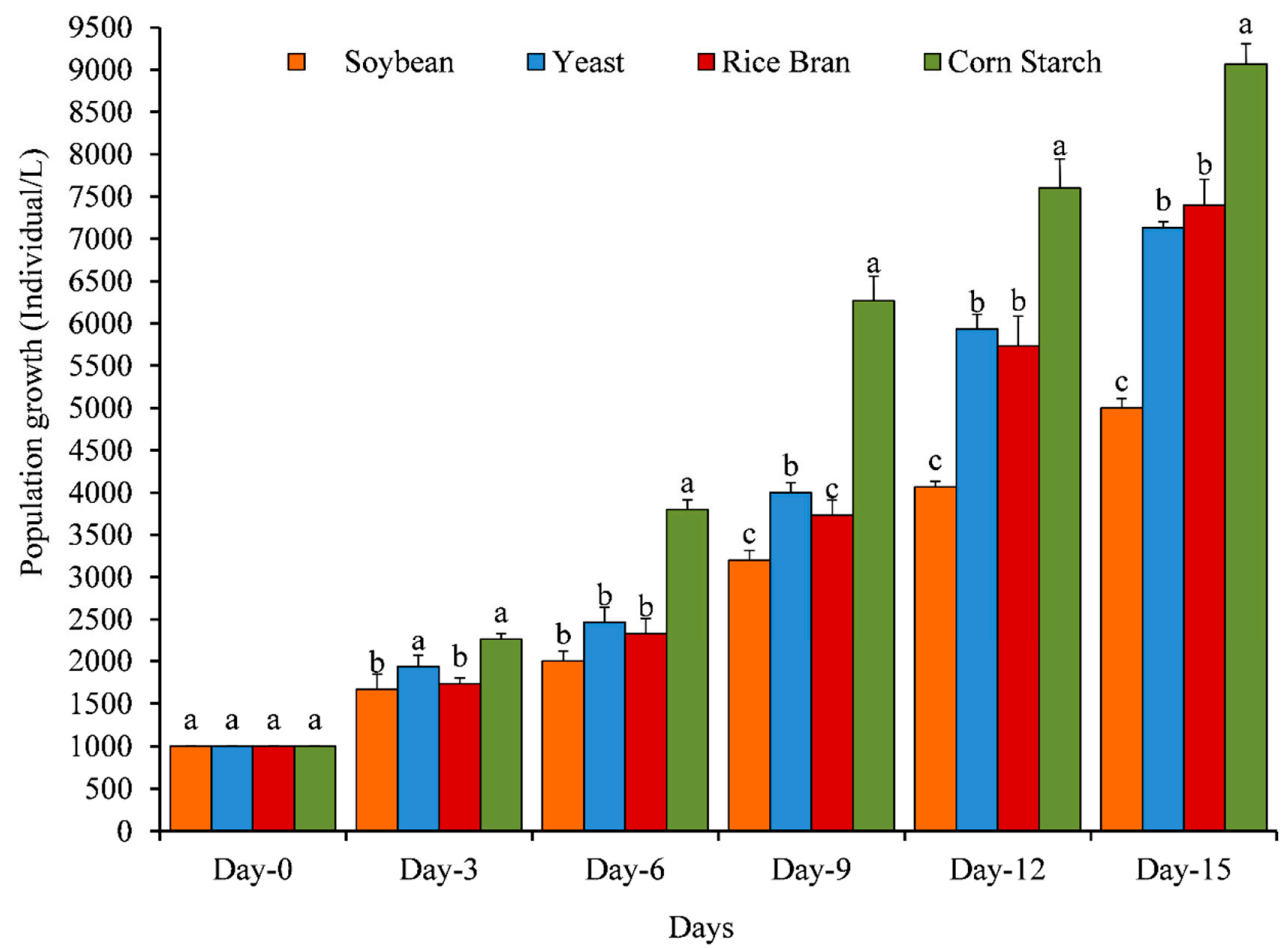

Figure 2. Effect of different diets on the population growth (individual $\mathrm{L}^{-1}$ ) of Cyclopoida copepod, Oithona nana. Data are presented as the mean \pm standard errors. The letters $(a, b$, and $c)$ above each bar indicate the significant differences $(p \leq 0.05)$ between different diets at the same day.

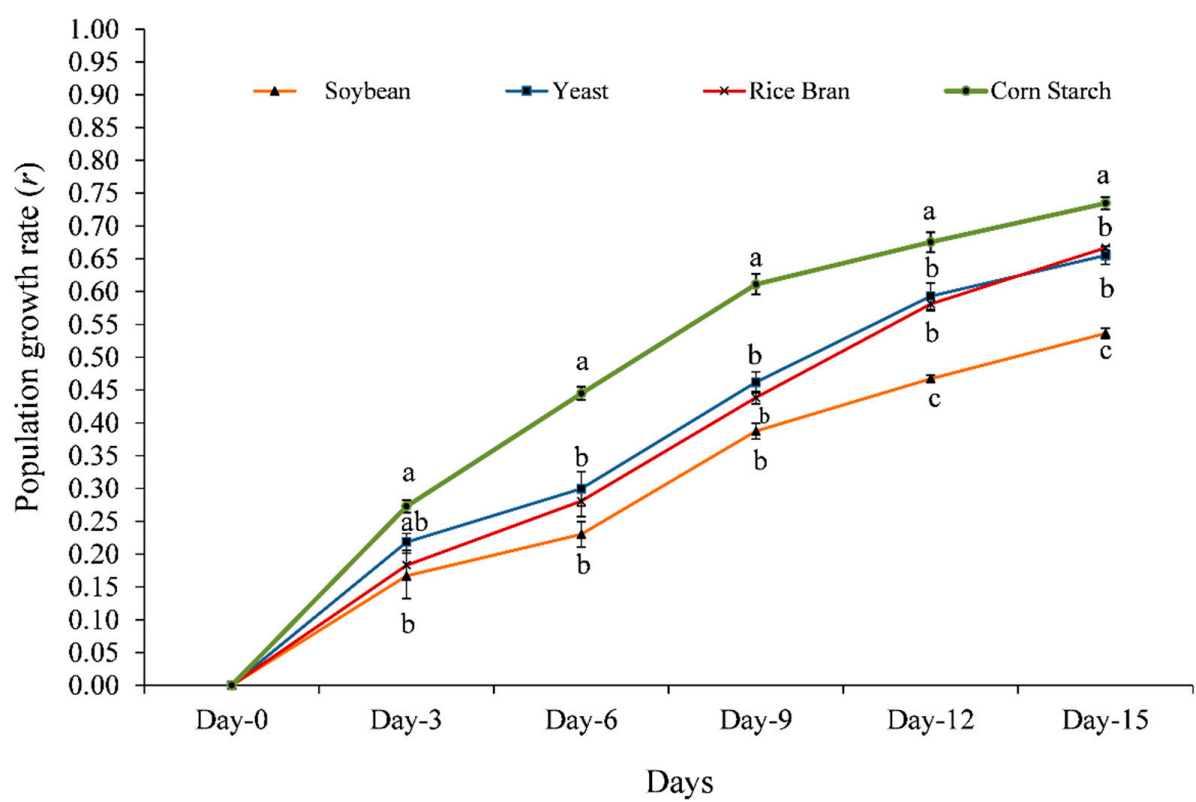

Figure 3. Effect of different diets on the population growth rate $(r)$ of Cyclopoida copepods, Oithona nana. Data are presented as mean \pm standard errors. The letters ( $\mathrm{a}, \mathrm{ab}, \mathrm{b}$, and $\mathrm{c}$ ) above each bar indicate the significant differences $(p \leq 0.05)$ among different diets on the same day. 


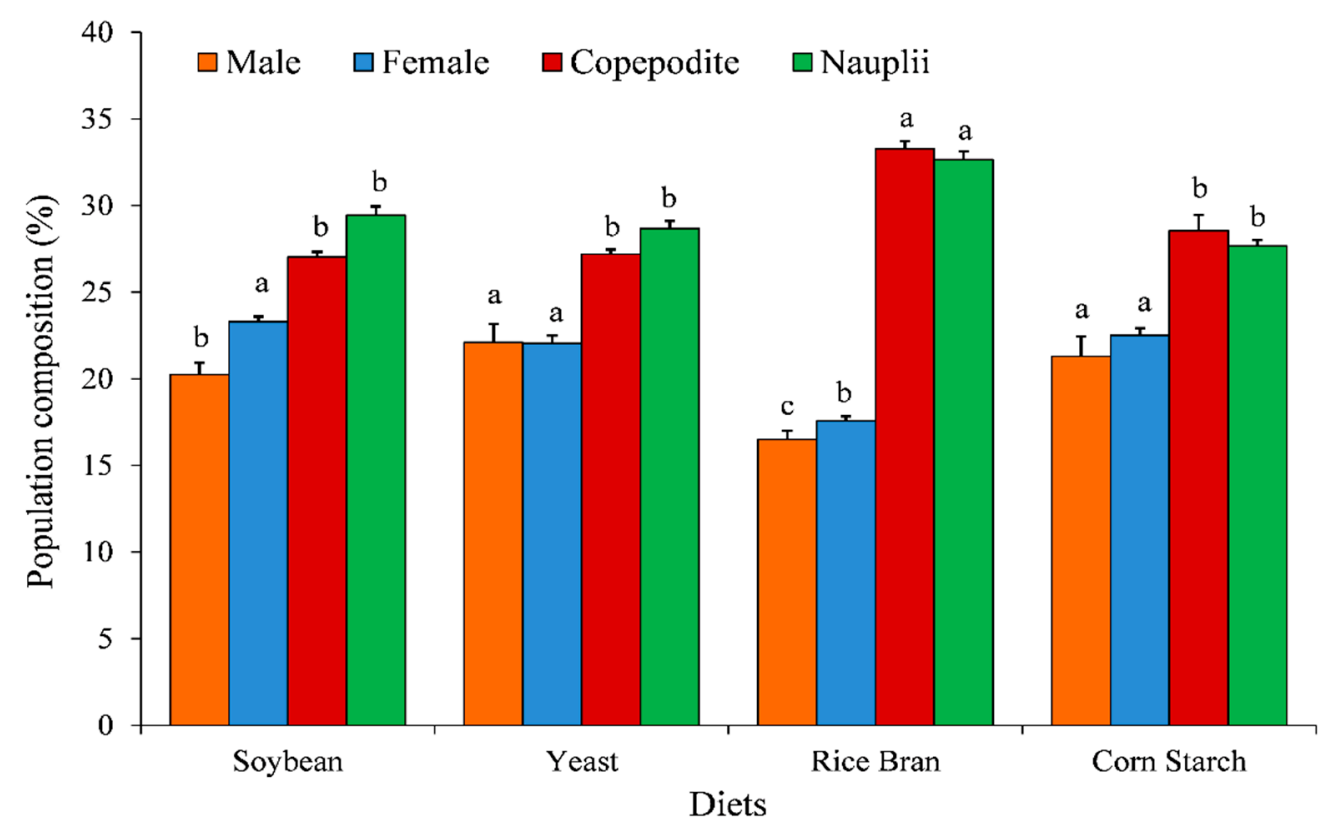

Figure 4. Effect of different diets on mean percentages of population compositions of Oithona nana. Data are presented as mean \pm standard errors. The letters $(\mathrm{a}, \mathrm{b}$, and $\mathrm{c})$ above each bar indicate the significant differences $(p \leq 0.05)$ between the developmental stages (adult males, adult females, nauplii, and copepodites) among the different diets.

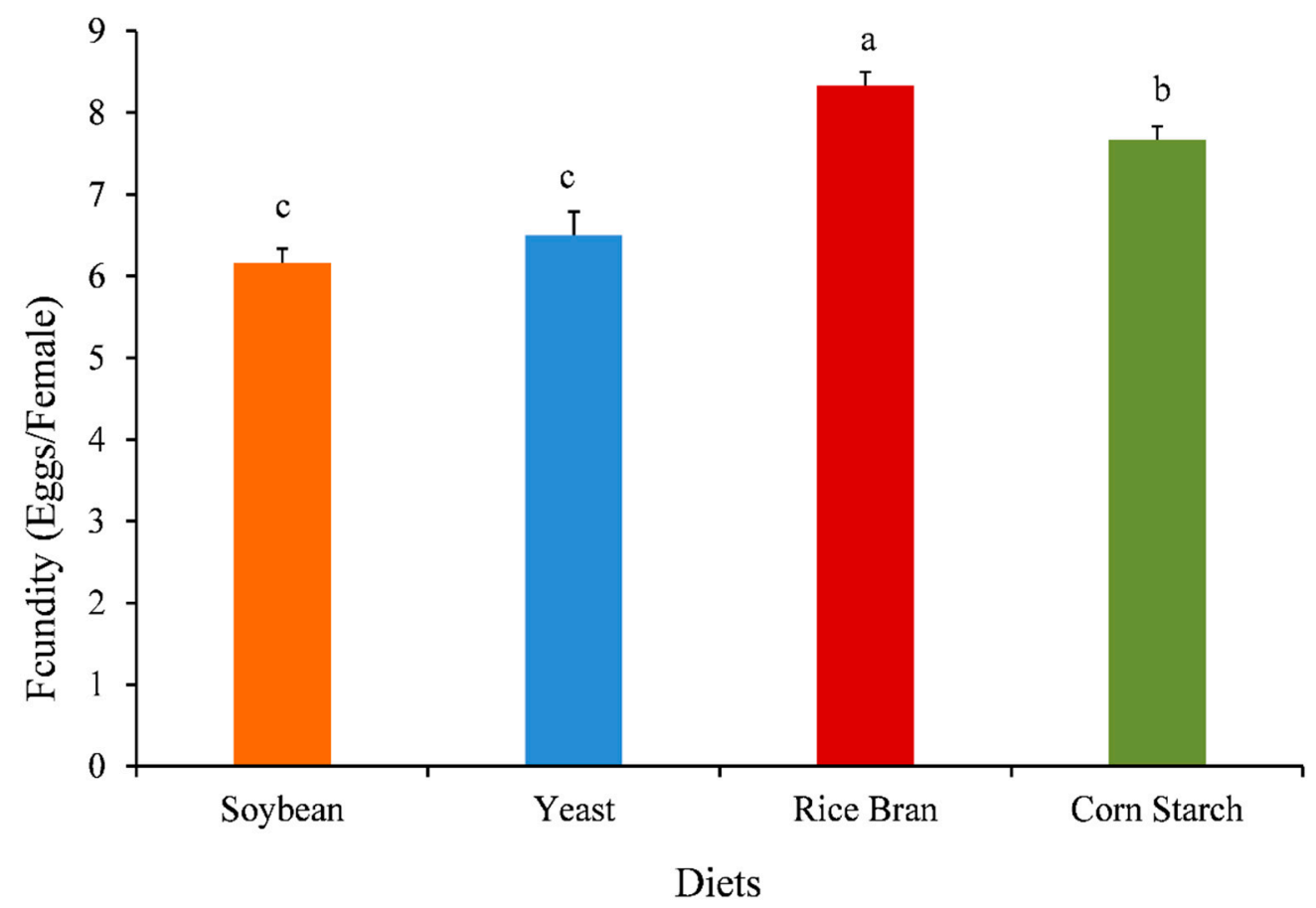

Figure 5. Effect of different diets on fecundity of Oithona nana. Data are presented as mean \pm standard errors. The letters (a, $\mathrm{b}$, and $\mathrm{c}$ ) above each bar indicate the significant differences $(p \leq 0.05)$ among the different diets.

Among all experimental diets, corn starch exhibited the highest significant $(p \leq 0.05)$ population growth and growth rate on all investigated days: namely day-3 (2267 Ind. $\mathrm{L}^{-1}$ and 0.273 , respectively); day-6 (3800 Ind. $\mathrm{L}^{-1}$ and 0.445 , respectively); day-9 (6267 Ind. $\mathrm{L}^{-1}$ and 0.611 , respectively); day- 12 (7600 Ind. $\mathrm{L}^{-1}$ and 0.675 , respectively); and day- 15 (0.967 Ind. $\mathrm{L}^{-1}$ and 0.735 , respectively) — followed by yeast and rice bran, while the lowest significant population growth (Figure 2) and growth rate (Figure 3) was observed with soybean. 
Figure 4 presented the percentages of the population composition (male, female, copepodite, and nauplii) of $O$. nana fed on different diets. The $O$. nana fed on rice bran diet revealed the highest significant copepodite and nauplii percentages $(33.27 \%$ and $32.65 \%$, respectively) and the lowest significant male and female percentages $(16.50 \%$ and $17.58 \%$, respectively), (Figure 4 ).

Figure 5 showed the fecundity (eggs female ${ }^{-1}$ ) of $O$. nana fed on different diets. $O$. nana fed on rice bran diet revealed the highest significant fecundity $(8.32 \pm 0.167$ eggs female $\left.{ }^{-1}\right)$, followed by the diet of corn starch $\left(7.67 \pm 0.159\right.$ eggs female $\left.{ }^{-1}\right)$, while the lowest significant fecundity was found in the diet of soybean $\left(6.17 \pm 0.177\right.$ eggs female $\left.{ }^{-1}\right)$ and yeast $\left(6.50 \pm 0.289\right.$ eggs female $\left.{ }^{-1}\right)$.

\subsection{Fatty Acid Compositions}

Fatty acid compositions were significantly varied in $O$. nana fed on the different diets (Table 1). Among all diets, $O$. nana fed on rice bran showed the highest significant $(p \leq 0.05)$ percentages of MUFA (34.87\%) and PUFA (1.45\%), as well as showed the lowest significant percentage of SFA (63.87\%) and the lowest SFA/UFA (1.77), compared to the other diets. Furthermore, O. nana fed on rice bran had a greater C18:1c (13.04\%), C18:3w3 (1.20\%). No recorded EPA (C20:5w3) in all O. nana fed on the different diets except the diet of rice bran which was the only that revealed a small amount of $(0.24 \%)$, as presented in Table 1.

Table 1. Fatty acid profiles of $O$. nana fed on different food regimes.

\begin{tabular}{ccccc}
\hline FA & Soybean & Yeast & Rice Bran & Starch \\
\hline SFA & & & & \\
C10:0 & $0.31 \pm 0.006^{\mathrm{d}}$ & $0.46 \pm 0.17^{\mathrm{a}}$ & $0.41 \pm 0.006^{\mathrm{b}}$ & $0.373 \pm 0.003^{\mathrm{c}}$ \\
C11:0 & $0.40 \pm 0.006^{\mathrm{c}}$ & $0.81 \pm 0.075^{\mathrm{a}}$ & $0.41 \pm 0.023^{\mathrm{c}}$ & $0.56 \pm 0.006^{\mathrm{b}}$ \\
C12:0 & $0.78 \pm 0.003^{\mathrm{ab}}$ & $0.88 \pm 0.058^{\mathrm{a}}$ & $0.70 \pm 0.020^{\mathrm{b}}$ & $0.52 \pm 0.035^{\mathrm{c}}$ \\
C13:0 & $2.17 \pm 0.040^{\mathrm{b}}$ & $2.87 \pm 0.055^{\mathrm{a}}$ & $2.39 \pm 0.205^{\mathrm{b}}$ & $3.10 \pm 0.159^{\mathrm{a}}$ \\
C14:0 & $10.51 \pm 0.309^{\mathrm{c}}$ & $17.80 \pm 0.820^{\mathrm{a}}$ & $14.15 \pm 0.471^{\mathrm{b}}$ & $16.10 \pm 0.393^{\mathrm{a}}$ \\
C15:0 & $0.91 \pm 0.147^{\mathrm{d}}$ & $2.60 \pm 0.101^{\mathrm{b}}$ & $1.99 \pm 0.012^{\mathrm{c}}$ & $11.80 \pm 0.115^{\mathrm{a}}$ \\
C16:0 & $38.54 \pm 0.12^{\mathrm{a}}$ & $24.78 \pm 0.303^{\mathrm{c}}$ & $30.48 \pm 0.029^{\mathrm{b}}$ & $24.83 \pm 0.245^{\mathrm{c}}$ \\
C17:0 & $0.55 \pm 0.003^{\mathrm{d}}$ & $1.92 \pm 0.043^{\mathrm{a}}$ & $1.16 \pm 0.015^{\mathrm{b}}$ & $0.69 \pm 0.003^{\mathrm{c}}$ \\
C18:0 & $21.88 \pm 0.245^{\mathrm{a}}$ & $11.57 \pm 0.205^{\mathrm{b}}$ & $9.76 \pm 0.064^{\mathrm{c}}$ & $8.12 \pm 0.090^{\mathrm{d}}$ \\
C20:4 & $0.83 \pm 0.046^{\mathrm{b}}$ & $2.65 \pm 0.191^{\mathrm{a}}$ & $2.43 \pm 0.300^{\mathrm{a}}$ & $2.22 \pm 0.049^{\mathrm{a}}$ \\
MUFA & & & & \\
C14:1 & $12.35 \pm 0.001^{\mathrm{b}}$ & $15.16 \pm 0.823^{\mathrm{a}}$ & $15.58 \pm 0.003^{\mathrm{a}}$ & $13.93 \pm 0.543^{\mathrm{ab}}$ \\
C15:1 & $0.77 \pm 0.015^{\mathrm{b}}$ & $1.32 \pm 0.001^{\mathrm{b}}$ & $1.16 \pm 0.479^{\mathrm{b}}$ & $4.37 \pm 0.150^{\mathrm{a}}$ \\
C16:1 & $1.89 \pm 0.020^{\mathrm{b}}$ & $4.19 \pm 0.592^{\mathrm{a}}$ & $2.44 \pm 0.032^{\mathrm{b}}$ & $2.33 \pm 0.040^{\mathrm{b}}$ \\
C18:1c & $6.22 \pm 0.150^{\mathrm{c}}$ & $9.07 \pm 0.297^{\mathrm{b}}$ & $13.04 \pm 0.069^{\mathrm{a}}$ & $9.02 \pm 0.433^{\mathrm{b}}$ \\
C18:2c & $1.04 \pm 0.104^{\mathrm{c}}$ & $2.77 \pm 0.015^{\mathrm{a}}$ & $2.46 \pm 0.006^{\mathrm{b}}$ & $1.12 \pm 0.012^{\mathrm{c}}$ \\
PUFA & & & \\
C18:3w3 & $0.83 \pm 0.038^{\mathrm{b}}$ & $1.18 \pm 0.017^{\mathrm{a}}$ & $1.20 \pm 0.061^{\mathrm{a}}$ & $0.91 \pm 0.012^{\mathrm{b}}$ \\
C20:5w3 & $0.00 \pm 0.000^{\mathrm{b}}$ & $0.00 \pm 0.000^{\mathrm{b}}$ & $0.24 \pm 0.006^{\mathrm{a}}$ & $0.00 \pm 0.000^{\mathrm{b}}$ \\
$\sum$ SFA & $76.89 \pm 0.297^{\mathrm{a}}$ & $66.33 \pm 0.479^{\mathrm{c}}$ & $63.87 \pm 0.647^{\mathrm{d}}$ & $68.32 \pm 0.084^{\mathrm{b}}$ \\
$\sum$ MUFA & $22.27 \pm 0.260^{\mathrm{d}}$ & $32.49 \pm 0.514^{\mathrm{b}}$ & $34.68 \pm 5.95^{\mathrm{a}}$ & $30.77 \pm 0.095^{\mathrm{c}}$ \\
$\sum$ PUFA & $0.83 \pm 0.037^{\mathrm{c}}$ & $1.18 \pm 0.017^{\mathrm{b}}$ & $1.45 \pm 0.055^{\mathrm{a}}$ & $0.91 \pm 0.012^{\mathrm{c}}$ \\
SFA/UFA & $3.33 \pm 0.058^{\mathrm{a}}$ & $1.97 \pm 0.043^{\mathrm{c}}$ & $1.77 \pm 0.052^{\mathrm{d}}$ & $2.16 \pm 0.009^{\mathrm{b}}$
\end{tabular}

Values are means \pm SE. Means $(n=3)$ in the same row with different superscript are significantly different $(p \leq 0.05)$. FA: fatty acids; SFA: saturated fatty acids; MUFA: monounsaturated fatty acids; PUFA: polyunsaturated fatty acids; UFA: unsaturated fatty acids.

\section{Discussion}

Cyclopoida copepods are the most suitable species for mass production [46-48]. However, the cost-efficient protocols for the mass production of copepods still need more development [49]. In addition to the low yields, long generation time, seasonal variations of production, and high costs are the main problems limiting the success of the culture of copepods $[10,49,50]$. Accordingly, there is a need for low-cost dry food to minimize the cost 
of copepod production [4]. These feedstuffs must be very applicable, more economic, and simply have the potential to be alternative diets to substitute microalgae, and maximize the fecundity and population of Cyclopoida copepods, O. nana [39].

In the current study, different diets (soybean, yeast, rice bran, and corn starch) were evaluated to select the suitable diet for maximizing the quantity (population growth, population growth rate, population composition, and fecundity) and quality (fatty acid composition) of O. nana. The commercial grades of soybean, yeast, rice bran, and corn starch did not show any negative effects on the water quality of the experimental aquariums. The growth and community composition of O. nana in the present study was comparable with the previous studies using macroalgae as a diet [31,51]. Meanwhile, each dry diet has a different pattern of modulating $O$. nana growth and quality. For instance, soybean, which is characterized by high protein percentage, appealing smell, low price [52], and low content of specific anti-nutrients, including oligosaccharides and allergic proteins [53]. However, the growth of $O$. nana in the present study with soybean had the lowest rate compared with other tested diets, which could be due to the high concentration of soybean meal, or nitrogen wastes and induced toxicity [54]. In the study of El-khodary et al. [27] who found that Cyclops fed on soybean had high density ( 27 individuals $\mathrm{mL}^{-1}$ ) but this diet provided low nutritional value compared with those fed on microalgae.

In marine hatcheries, Baker's yeast, Saccharomyces cerevisiae, could be successively used as an algal substitute. Moreover, it has obvious benefits, like the reduction in algal production facilities and subsequently reducing the production cost. Many authors cited that the low concentration of yeast did not influence water quality $[27,32,33]$. Rice bran was successfully used as feed for copepods, daphnia, artemia, and moina cultures [35,41,42]. Amian et al. [36] cited that the diversity and abundance of Copepoda, Rotifera, and Cladocera were enhanced when using rice bran in fishponds during the rearing of tilapia. Rice bran, as well as soybean, must be processed into small particle suspension to fit the mouth of the cultured copepods [27,36,42].

In addition, the current findings revealed that the diets significantly affected the quality and quantity of $O$. nana. The highest significant maximum population density and population growth rate were observed with copepods $O$. nana fed on corn starch diet. Our results were in agreement with Sulehria et al. [37], who cited that rotifers cultured with corn starch resulted with relatively high growth. As cited by Tester et al. [55], the starch grains are composed of two types of alpha-glucan, amylopectin and amylose, which substitute approximately $98 \%-99 \%$ of the dry weight of starch, moreover, starch contains relatively low quantities $(0.4 \%)$ of minerals. Moreover, the current study indicated that $O$. nana fed on rice barn diet had a higher fecundity $\left(8.33\right.$ eggs female $\left.^{-1}\right)$ compared with those fed on soybean, yeast, and corn starch $(6.17,6.50$, and 7.67 , respectively). Carli et al. [56] reported that the type of diets is strongly affecting the fecundity and survival of Harpacticoida Copepoda, Tigriopus fulvus. Previous studies have confirmed that the fecundity of copepods can probably be linked to the content of PUFA in their diets [23,25,57]. The importance of dietary PUFA contents to the fecundity of $O$. nana was detected in the experimental diets.

In the current study, the fatty acids composition of copepods fed on a rice bran diet may explain the increase in female fecundity obtained by this diet, compared to the other diets. In the current study, comparing to the fatty acid compositions of copepods fed on soybean, yeast, and corn starch, the fatty acid composition of copepods fed on rice bran resulted in the highest significant MUFA and PUFA, as well as the lowest significant SFA and the lowest SFA/UFA ratio. These findings may be due to the nutritional value of rice bran [35,41]. Bhat et al. [58] cited that commercial grade rice bran contains 50\% carbohydrate, $15 \%$ protein, 20\% fatty acids (linoleic and oleic acids), 5\% Vitamin E (tocatrienols, tocopherols, oryzanols, phytosterols), and a low amount of other micronutrients.

The fatty acid profiles of copepods and its diets are very important, not only for assessing their aquaculture potential $[24,59]$, but also for understanding and investigating the trophic ecology of copepods [60,61]. Many authors cited that copepods have the ability to endogenously synthesize PUFA from short-chain fatty acids [31,62]. The ability of fatty 
acid transformation in copepods is species-specific [51]. Harpacticoida and Cyclopoida copepods are reported to be able to synthesize the long-chain fatty acids, especially EPA and DHA, from dietary short-chain fatty acids $[51,62,63]$. Interestingly, the copepods fed on rice bran are the only exhibited EPA in their fatty acid profile compared to the copepods fed on other diets. These findings may be attributed to the nutritional value of rice bran. Moreover, the EPA contents of copepod fed on rice bran may explain the high obtained fecundity, as well as the high significant percentage of nauplii $(32.65 \%)$ and copepodite $(33.27 \%)$ in the population composition of $O$. nana. In current study, although utilizing dry feeds by $O$. nana, the previous findings may explain the improving in fecundity and density of O. nana. The observed trend of fecundity was similar to the examination of population composition, since rice bran provided the highest total percentage of nauplii and copepodite population. In addition, the rice bran diet was markedly predominated by nauplii and copepodite, with relatively few adult males and/or females, as shown in (Figure 4). Our finding is in agreement with the results of Pan et al. [25] who cited that the high PUFA content of the diet positively affected the fecundity, nauplii, and copepodite population of Copepoda, Apocyclops royi; moreover, he recommends that the marine microalgae Isochrysis galbana and Nannochloropsis oculata are the optimal diet for supporting the population growth and superior fatty acid profile of Copepoda, Apocyclops royi. Therefore, recently, the continuous screening and isolation of aquatic organisms have important implications in terms of sustaining and developing aquaculture $[29,39,64]$.

\section{Conclusions}

The current work concluded that, among the experimental diets (soybean, yeast, rice bran, and corn starch), rice bran is the best diet for culturing O. nana, since it achieved a high percentage of nauplii and copepodite, maximum fecundity, and improved the fatty acid profiles, especially the PUFA content of $O$. nana. On the other hand, the corn starch was more suitable for improving the maximum population density and the maximum growth rate of cultured $O$. nana. Finally, it may be concluded that the dry feeds protocol described in the present study are very useful and applicable for maximizing the fecundity and density of Oithona nana (Cyclopoida, Copepoda).

Author Contributions: Conceptualization, F.I.M., M.A.E., M.M. and M.A. (Mohamed Ashour); methodology, F.I.M., M.A.E., M.M. and M.A. (Mohamed Ashour); software, A.T.M., M.A. (Mohamed Alkafafy) and M.A. (Mohamed Ashour); validation, F.I.M., M.A.E., M.M. and M.A. (Mohamed Alkafafy); formal analysis, F.I.M., M.A.E., M.M., M.A. (Mohamed Alkafafy) and A.T.M.; investigation, A.T.M., M.M. and F.I.M.; resources, M.M., A.T.M. and M.A. (Mohamed Alkafafy); data curation, M.M., A.T.M. and M.A. (Mohamed Alkafafy); writing-original draft preparation, M.A. (Mohamed Ashour); writing-review and editing, A.T.M. and M.A. (Mohamed Ashour); visualization, F.I.M., M.M. and M.A. (Mohamed Ashour); supervision, F.I.M. and M.A.E.; project administration, F.I.M. and M.A.E.; funding acquisition, M.M. and M.A. (Mohamed Alkafafy) All authors have read and agreed to the published version of the manuscript.

Funding: This research was funded by Taif University Researchers Supporting Project number (TURSP-2020/57), Taif university, Taif, Saudi Arabia.

Institutional Review Board Statement: The study was approved and conducted according to the guidelines of The Committee of Local Experiment Animal Care (Number 4/2016EC), Faculty of Agriculture, Kafrelsheikh University, Egypt.

Informed Consent Statement: Not applicable.

Data Availability Statement: The data that support the findings of this study are available from the authors upon reasonable request.

Acknowledgments: Taif University Researchers Supporting Project number (TURSP-2020/57), Taif University, P.O. Box 11099, Taif 21944, Saudi Arabia.

Conflicts of Interest: The authors declare no conflict of interest. 


\section{References}

1. Khairy, H.M.; El-Sayed, H.S. Effect of enriched Brachionus plicatilis and Artemia salina nauplii by microalga Tetraselmis chuii (Bütcher) grown on four different culture media on the growth and survival of Sparus aurata larvae. Afr. J. Biotechnol. 2012, 11, 399-415.

2. Abdel-Rahman, S.; Abdel Razek, F.; AbouZeid, A.; Ashour, M. Population growth rate, fecundity, filtration and ingestion rate of marine rotifer Brachionus plicatilis fed with motile and immotile microalgae. Egypt. J. Aquat. Res. 2008, 34, 426-439.

3. Abdel-Rahman, H.; Abdel Razek, A.; AbouZeid, A.; Ashour, M. Optimum growth conditions of three isolated diatoms species Skeletonema costatum, Chaetoceros calcitrans and Detonula confervacea and their utilization as feed for marine penaeid shrimp larvae. Egypt. J. Aquat. Res. 2010, 36, 161-183.

4. Drillet, G.; Frouël, S.; Sichlau, M.H.; Jepsen, P.M.; Højgaard, J.K.; Joarder, A.K.; Hansen, B.W. Status and recommendations on marine copepod cultivation for use as live feed. Aquaculture 2011, 315, 155-166. [CrossRef]

5. Sharawy, Z.Z.; Ashour, M.; Abbas, E.; Ashry, O.; Helal, M.; Nazmi, H.; Kelany, M.; Kamel, A.; Hassaan, M.; Rossi Jr, W. Effects of dietary marine microalgae, Tetraselmis suecica, on production, gene expression, protein markers and bacterial count of Pacific white shrimp Litopenaeus vannamei. Aquac. Res. 2020, 51, 2216-2228. [CrossRef]

6. Abo-Taleb, H.; Ashour, M.; El-Shafei, A.; Alataway, A.; Maaty, M.M. Biodiversity of Calanoida Copepoda in Different Habitats of the North-Western Red Sea (Hurghada Shelf). Water 2020, 12, 656. [CrossRef]

7. El-Gamal, M.M.; Othman, S.I.; Abdel-Rahim, M.M.; Mansour, A.T.; Alsaqufi, A.S.; El Atafy, M.M.; Mona, M.H.; Allam, A.A. Palaemon and artemia supplemented diet enhances sea bass, Dicentrarchus labrax, broodstock reproductive performance and egg quality. Aquac. Rep. 2020, 16, 100290. [CrossRef]

8. Heneash, A.; Ashour, M.; Matar, M. Effect of Un-live Microalgal diet, Nannochloropsis oculata and Arthrospira (Spirulina) platensis, comparing to yeast on population of rotifer, Brachionus plicatilis. Mediterr. Aquac. J. 2015, 7, 48-54. [CrossRef]

9. Ashour, M.; Elshobary, M.E.; El-Shenody, R.; Kamil, A.-W.; Abomohra, A.E.-F. Evaluation of a native oleaginous marine microalga Nannochloropsis oceanica for dual use in biodiesel production and aquaculture feed. Biomass Bioenergy 2019, 120, 439-447. [CrossRef]

10. Støttrup, J. The elusive copepods: Their production and suitability in marine aquaculture. Aquac. Res. 2000, 31, 703-711. [CrossRef]

11. Olivotto, I.; Tokle, N.; Nozzi, V.; Cossignani, L.; Carnevali, O. Preserved copepods as a new technology for the marine ornamental fish aquaculture: A feeding study. Aquaculture 2010, 308, 124-131. [CrossRef]

12. Abate, T.G.; Nielsen, R.; Nielsen, M.; Jepsen, P.M.; Hansen, B.W. A cost-effectiveness analysis of live feeds in juvenile turbot Scophthalmus maximus (Linnaeus, 1758) farming: Copepods versus A rtemia. Aquac. Nutr. 2016, 22, 899-910. [CrossRef]

13. Øie, G.; Galloway, T.; Sørøy, M.; Holmvaag Hansen, M.; Norheim, I.; Halseth, C.; Almli, M.; Berg, M.; Gagnat, M.; Wold, P.A. Effect of cultivated copepods (Acartia tonsa) in first-feeding of Atlantic cod (Gadus morhua) and ballan wrasse (Labrus bergylta) larvae. Aquac. Nutr. 2017, 23, 3-17. [CrossRef]

14. Abdel-Rahim, M.M.; Mansour, A.T.; Mona, M.H.; El-Gamal, M.M.; El Atafy, M.M. To what extent can maternal inherited immunity acquired from a crustacean-enhanced diet improve the performance and vitality of the offspring and enhance profitability of European Sea bass (Dicentrarchus labrax)? J. World Aquac. Soc. 2019, 50, 550-574. [CrossRef]

15. Blaxter, J.H.; Douglas, B.; Tyler, P.A.; Mauchline, J. The Biology of Calanoid Copepods; Academic Press: Cambridge, MA, USA, 1998.

16. Støttrup, J. Production and nutritional value of copepods. In Live Feeds in Marine Aquaculture; Støttrup, J., McEvoy, L., Eds.; Blackwell: Oxford, UK, 2003; p. 318.

17. Lee, C.; O’Bryen, P.; Marcus, N. Copepods in Aquaculture; Wiley-Blackwell: Oxford, UK, 2005.

18. Ashour, M.; Abo-Taleb, H.; Abou-Mahmoud, M.; El-Feky, M. Effect of the integration between plankton natural productivity and environmental assessment of irrigation water, El-Mahmoudia Canal, on aquaculture potential of Oreochromis niloticus. Turk. J. Fish. Aquatic Sci. 2018, 18, 1163-1175.

19. Abo-Taleb, H.; Zeina, A.F.; Ashour, M.; Mabrouk, M.M.; Sallam, A.E.; El-feky, M.M. Isolation and cultivation of the freshwater amphipod Gammarus pulex (Linnaeus, 1758), with an evaluation of its chemical and nutritional content. Egypt. J. Aquat. Biol. Fish. 2020, 24, 69-82. [CrossRef]

20. Turner, J.T. The importance of small planktonic copepods and their roles in pelagic marine food webs. Zool. Stud. 2004, 43, 255-266.

21. Albano, M.; Panarello, G.; Di Paola, D.; D'Angelo, G.; Granata, A.; Savoca, S.; Capillo, G. The mauve stinger Pelagia noctiluca (Cnidaria, Scyphozoa) plastics contamination, the Strait of Messina case. Int. J. Environ. Stud. 2021, 1-6. [CrossRef]

22. Yamaguchi, A.; Matsuno, K.; Homma, T. Spatial changes in the vertical distribution of calanoid copepods down to great depths in the North Pacific. Zool. Stud. 2015, 54, 1-12. [CrossRef]

23. Kleppel, G.; Hazzard, S.; Burkart, C. Maximizing the nutritional values of copepods in aquaculture: Managed versus balanced nutrition. In Copepods in Aquaculture; Lee, C.S., O’Bryen, P.J., Marcus, N.H., Eds.; Blackwell Publishing: Oxford, UK, 2005; pp. 49-60.

24. Van der Meeren, T.; Olsen, R.E.; Hamre, K.; Fyhn, H.J. Biochemical composition of copepods for evaluation of feed quality in production of juvenile marine fish. Aquaculture 2008, 274, 375-397. [CrossRef]

25. Pan, Y.-J.; Souissi, A.; Souissi, S.; Hwang, J.-S. Effects of salinity on the reproductive performance of Apocyclops royi (Copepoda, Cyclopoida). J. Exp. Mar. Biol. Ecol. 2016, 475, 108-113. [CrossRef] 
26. Vidhya, K.; Uthayakumar, V.; Muthukumar, S.; Munirasu, S.; Ramasubramanian, V. The effects of mixed algal diets on population growth, egg productivity and nutritional profiles in cyclopoid copepods (Thermocyclops hyalinus and Mesocyclops aspericornis). J. Basic Appl. Zool. 2014, 67, 58-65. [CrossRef]

27. El-khodary, G.M.; Mona, M.M.; El-sayed, H.S.; Ghoneim, A.Z. Phylogenetic identification and assessment of the nutritional value of different diets for a copepod species isolated from Eastern Harbor coastal region. Egypt. J. Aquat. Res. 2020, 46, 173-180. [CrossRef]

28. Elshobary, M.E.; El-Shenody, R.A.; Ashour, M.; Zabed, H.M.; Qi, X. Antimicrobial and antioxidant characterization of bioactive components from Chlorococcum minutum. Food Biosci. 2020, 35, 100567. [CrossRef]

29. Zaki, M.A.; Ashour, M.; Heneash, A.M.; Mabrouk, M.M.; Alprol, A.E.; Khairy, H.M.; Nour, A.M.; Mansour, A.T.; Hassanien, H.A.; Gaber, A. Potential Applications of native cyanobacterium isolate (Arthrospira platensis NIOF17/003) for biodiesel production and utilization of its byproduct in marine rotifer (Brachionus plicatilis) production. Sustainability 2021, 13, 1769. [CrossRef]

30. Ashour, M. Current and future perspectives of microalgae-aquaculture in Egypt, case study: SIMAF-prototype-project. Egypt. J. Anim. Prod. 2020, 57, 163-170.

31. Lee, K.W.; Park, H.G.; Lee, S.-M.; Kang, H.-K. Effects of diets on the growth of the brackish water cyclopoid copepod Paracyclopina nana Smirnov. Aquaculture 2006, 256, 346-353. [CrossRef]

32. Payne, M.; Rippingale, R. Evaluation of diets for culture of the calanoid copepod Gladioferens imparipes. Aquaculture 2000, 187, 85-96. [CrossRef]

33. Farhadian, O.; Yusoff, F.M.; Arshad, A. Population growth and production of Apocyclops dengizicus (Copepoda: Cyclopoida) fed on different diets. J. World Aquac. Soc. 2008, 39, 384-396. [CrossRef]

34. Ribeiro, A.C.; Souza-Santos, L.P. Mass culture and offspring production of marine harpacticoid copepod Tisbe biminiensis. Aquaculture 2011, 321, 280-288. [CrossRef]

35. Mubarak, A.S.; Jusadi, D.; Junior, M.Z.; Suprayudi, M.A. The population growth and the nutritional status of Moina macrocopa feed with rice bran and cassava bran suspensions. J. Akuakultur Indones. 2017, 16, 223-233. [CrossRef]

36. Amian, A.; Etile, R.; Aka, M.; Wandan, E.; Blé, C. Zooplankton diversity and abundance in extensive fish ponds during the rearing of tilapia Oreochromis niloticus juveniles fed with rice bran (West Africa, Côte d'Ivoire). Int. J. Fish. Aquat. Stud. 2018, 6, 131-136.

37. Sulehria, A.Q.K.; Younus, I.; Hussain, A. Effect of artificial diets on the growth and survival of rotifers. Biologia 2010, 56, 31-37.

38. Gyllenberg, G.; Lundqvist, G. Utilization of dissolved glucose by two copepod species. Ann. Zool. Fenn. 1978, $15,323-327$.

39. Magouz, F.I.M.M.; Essa, M.A.; El-Shafei, A.; Mansour, A.T.; Mahmoud, S.m.; Ashour, M. Effect of extended feeding with live copepods, Oithona nana, and Artemia franciscana on the growth performance, intestine histology, and economic viability of european seabass (Dicentrarchus labrax) postlarvae. Fresenius Environ. Bull. 2021, 7106-7116.

40. Ashour, M.; Mabrouk, M.M.; Ayoub, H.F.; El-Feky, M.M.; Zaki, S.Z.; Hoseinifar, S.H.; Rossi, W.; Van Doan, H.; El-Haroun, E.; Goda, A.M.-S. Effect of dietary seaweed extract supplementation on growth, feed utilization, hematological indices, and non-specific immunity of Nile Tilapia, Oreochromis niloticus, challenged with, Aeromonas hydrophila. J. Appl. Phycol. 2020, 32, 3467-3479. [CrossRef]

41. Sorgeloos, P.; Baeza-Mesa, M.; Bossuyt, E.; Bruggeman, E.; Dobbeleir, J.; Versichele, D.; Laviña, E.; Bernardino, A. Culture of Artemia on rice bran: The conversion of a waste-product into highly nutritive animal protein. Aquaculture 1980, 21, 393-396. [CrossRef]

42. Yamasaki, S.; Canto, J. Culture experiments on the harpacticoid copepod, Tisbintra elongata Mori, and evaluation of that species as a food organism for milkfish larvae. Memoirs Faculty Fish. Kagoshima Univ. 1980, 29, 275-291.

43. Tseng, L.-C.; Dahms, H.-U.; Chen, Q.-C.; Hwang, J.-S. Copepod feeding study in the upper layer of the tropical South China Sea. Helgol. Mar. Res. 2009, 63, 327-337. [CrossRef]

44. Yin, X.W.; Min, W.W.; Lin, H.J.; Chen, W. Population dynamics, protein content, and lipid composition of Brachionus plicatilis fed artificial macroalgal detritus and Nannochloropsis sp. diets. Aquaculture 2013, 380, 62-69. [CrossRef]

45. El-Shenody, R.A.; Ashour, M.; Ghobara, M.M.E. Evaluating the chemical composition and antioxidant activity of three Egyptian seaweeds: Dictyota dichotoma, Turbinaria decurrens, and Laurencia obtusa. Brazil. J. Food Technol. 2019, 22, e2018203. [CrossRef]

46. Schipp, G.R.; Bosmans, J.M.; Marshall, A.J. A method for hatchery culture of tropical calanoid copepods, Acartia spp. Aquaculture 1999, 174, 81-88. [CrossRef]

47. Peck, M.A.; Holste, L. Effects of salinity, photoperiod and adult stocking density on egg production and egg hatching success in Acartia tonsa (Calanoida: Copepoda): Optimizing intensive cultures. Aquaculture 2006, 255, 341-350. [CrossRef]

48. Chilmawati, D. The effect of different diet of phytoplankton cells on growth performance of Copepod, Oithona sp. in semi-mass culture. Aquat. Proc. 2016, 7, 39-45. [CrossRef]

49. Ajiboye, O.; Yakubu, A.; Adams, T.; Olaji, E.; Nwogu, N. A review of the use of copepods in marine fish larviculture. Rev. Fish Biol. Fish. 2011, 21, 225-246. [CrossRef]

50. Conceição, L.E.; Yúfera, M.; Makridis, P.; Morais, S.; Dinis, M.T. Live feeds for early stages of fish rearing. Aquac. Res. 2010, 41, 613-640. [CrossRef]

51. Pan, Y.J.; Sadovskaya, I.; Hwang, J.S.; Souissi, S. Assessment of the fecundity, population growth and fatty acid composition of Apocyclops royi (Cyclopoida, Copepoda) fed on different microalgal diets. Aquac. Nutr. 2018, 24, 970-978. [CrossRef]

52. Booman, M.; Forster, I.; Vederas, J.C.; Groman, D.B.; Jones, S.R. Soybean meal-induced enteritis in Atlantic salmon (Salmo salar) and Chinook salmon (Oncorhynchus tshawytscha) but not in pink salmon (O. gorbuscha). Aquaculture 2018, 483, 238-243. [CrossRef] 
53. FAO. FAOSTAT; Food and Agriculture Organization of the United Nations: Rome, Italy, 2011.

54. Martins, G.P.; Pezzato, L.E.; Guimaraes, I.G.; Padovani, C.R.; Mazini, B.S.M.; Barros, M.M. Antinutritional factors of raw soybean on growth and haematological responses of Nile tilapia. Boletim do Instituto de Pesca 2017, 43, 322-333. [CrossRef]

55. Tester, R.F.; Karkalas, J.; Qi, X. Starch-composition, fine structure and architecture. J. Cereal Sci. 2004, 39, 151-165. [CrossRef]

56. Carli, A.; Mariottini, G.; Pane, L. Influence of nutrition on fecundity and survival in Tigriopus fulvus Fischer (Copepoda: Harpacticoida). Aquaculture 1995, 134, 113-119. [CrossRef]

57. Støttrup, J.G.; Jensen, J. Influence of algal diet on feeding and egg-production of the calanoid copepod Acartia tonsa Dana. J. Exp. Mar. Biol. Ecol. 1990, 141, 87-105. [CrossRef]

58. Bhat, N.A.; Rainaand, R.; Wanganeo, A. Ecological investigation of zooplankton abundance in the Bhoj wetland, Bhopal of central India: Impact of environmental variables. Int. J. Fish. Aquac. 2015, 7, 81-93.

59. Rayner, T.A.; Jørgensen, N.O.; Blanda, E.; Wu, C.-H.; Huang, C.-C.; Mortensen, J.; Hwang, J.-S.; Hansen, B.W. Biochemical composition of the promising live feed tropical calanoid copepod Pseudodiaptomus annandalei (Sewell 1919) cultured in Taiwanese outdoor aquaculture ponds. Aquaculture 2015, 441, 25-34. [CrossRef]

60. Dalsgaard, J.; John, M.S.; Kattner, G.; Müller-Navarra, D.; Hagen, W. Fatty acid trophic markers in the pelagic marine environment. Adv. Mar. Biol. 2003, 46, 225-340. [PubMed]

61. El-Sabaawi, R.; Dower, J.F.; Kainz, M.; Mazumder, A. Characterizing dietary variability and trophic positions of coastal calanoid copepods: Insight from stable isotopes and fatty acids. Mar. Biol. 2009, 156, 225-237. [CrossRef]

62. Monroig, Ó.; Tocher, D.R.; Navarro, J.C. Biosynthesis of polyunsaturated fatty acids in marine invertebrates: Recent advances in molecular mechanisms. Mar. Drugs 2013, 11, 3998-4018. [CrossRef]

63. Rasdi, N.W.; Qin, J.G.; Li, Y. Effects of dietary microalgae on fatty acids and digestive enzymes in copepod C yclopina kasignete, a potential live food for fish larvae. Aquac. Res. 2016, 47, 3254-3264. [CrossRef]

64. Abbas, E.M.; Ali, F.S.; Desouky, M.G.; Ashour, M.; El-Shafei, A.; Maaty, M.M.; Sharawy, Z.Z. Novel comprehensive molecular and ecological study introducing coastal mud shrimp (Solenocera crassicornis) recorded at the Gulf of suez, Egypt. J. Mar. Sci. Eng. 2021, 9, 9. [CrossRef] 